\title{
Mário de Sá-Carneiro e Oscar Wilde: apoteoses
}
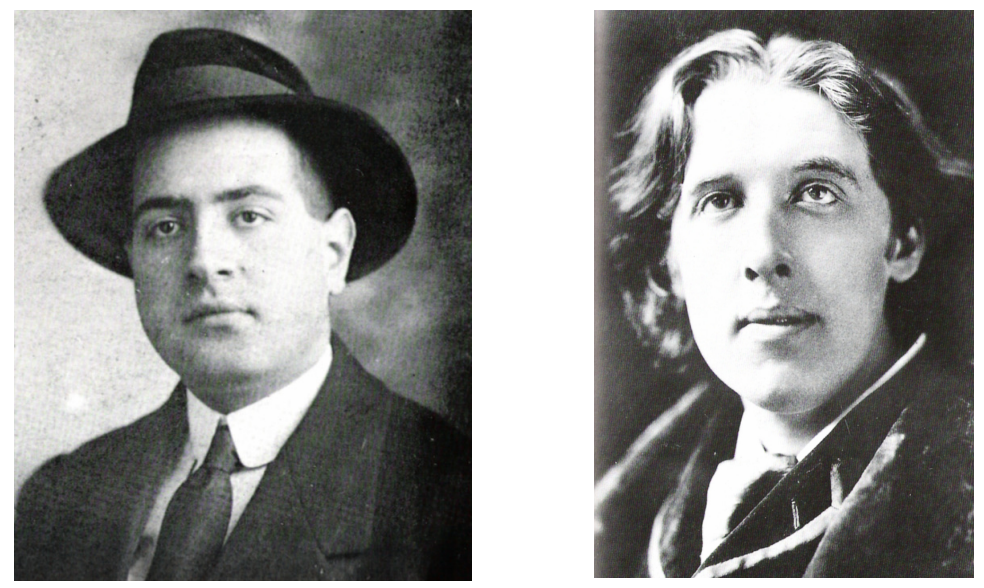

Ermelinda Maria Araújo Ferreira Universidade Federal de Pernambuco

A única desculpa de haver feito uma coisa inútil é admirála intensamente. Toda arte é completamente inútil.

Oscar Wilde

Por isso a sensação em mim fincada há tanto/Dum grande patrimônio algures haver perdido;/Por isso o meu desejo astral de luxo desmedido/E a Cor na minha Obra o que restou do encanto...

Mário de Sá-Carneiro

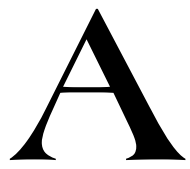

primeira vez que julguei perceber uma flagrante similaridade entre o poeta Mário de Sá-Carneiro (1890-1916) e o escritor

Oscar Wilde (1854-1900) foi durante a minha leitura da única novela escrita pelo português, A confissão de Lúcio, porque o final pareceu-me uma reedição do rocambolesco desfecho da única novela 
escrita pelo irlandês, O retrato de Dorian Gray, que utilizam, ambas, o tema do duplo para falar de questões não só estéticas, mas também éticas e existenciais. Além disso, o enredo da novela de Mário, que sugere, a partir da confissão de um ex-presidiário, a revelação dissimulada de sua nunca inteiramente assumida homossexualidade, parece buscar inspiração na história de vida do próprio Oscar Wilde, preso na Inglaterra em 1895 sob a acusação de homossexualismo, à época considerado um crime.

Na novela de Sá-Carneiro, o poeta Lúcio, narrador da história e apaixonado pelo também poeta Ricardo de Loureiro, envolve-se com "Marta", mulher do amigo. Projetando-a fantasticamente como o duplo de Ricardo a fim de satisfazer os desejos de Lúcio, que só admitia amar fisicamente uma mulher, o autor da Confissão transforma o seu protagonista na principal testemunha de um estranho crime: no final da história, Ricardo dispara um tiro contra a moça, que desaparece subitamente, enquanto o próprio Ricardo cai morto no chão, atingido pela bala. Sem poder explicar o absurdo do crime, Lúcio é condenado à prisão pelo assassinato do amigo, confessando a sua inocência num livro, dez anos depois.

Em O retrato de Dorian Gray, o jovem e belo Dorian é preservado, por obra da magia literária, de contemplar no próprio rosto a imagem de sua degeneração física, moral e espiritual. Os traços de sua decadência, porém, vão-se transferindo para um quadro que o retrata, maculando-o. Certa noite, não suportando ver os seus crimes estampados no retrato, enterra na tela a mesma faca com que acabara de matar seu amigo Basil Hallward, o autor da pintura. Quando os criados entram no quarto, encontram o quadro exposto em sua esplêndida pujança original. No chão, porém, jaz um homem com uma faca cravada no coração. Era velho, cheio de rugas e seu rosto inspirava repugnância. Só o identificaram como Dorian Gray quando examinaram os anéis que usava.

A semelhança do recurso da substituição das imagens usado por ambos no desfecho fantástico de suas novelas abre caminho para uma série infindável de especulações. Embora não se disponha de informações sobre o eventual conhecimento que Mário possa ter tido da obra de Wilde, é possível que ele tenha lido ou visto alguma coisa a respeito nas suas andanças por Paris, para onde Wilde se dirigia regularmente desde meados de 1880, a fim de experimentar uma cultura diferente, e onde acabou por morrer e ser sepultado, quase como indigente e em cova de aluguel, à semelhança do que ocorreria com Mário anos depois. 
O retrato de Dorian Gray chegou a ser descrito como o único romance francês escrito em língua inglesa, e a peça Salomé foi efetivamente escrita em francês, para ser encenada nesta língua, embora Wilde a tenha traduzido, mais tarde, para o inglês. A influência dos decadentistas franceses, como Baudelaire, é marcante tanto no poeta irlandês como no português, justificando, em parte, alguns dos possíveis ecos que se percebem em suas obras. Mas como as passagens de Wilde pela França eram acompanhadas de grande espalhafato na imprensa e nos meios intelectuais, não é de todo improvável que Mário tenha tido a oportunidade de ler algum texto de Wilde, em francês (não consta que falasse inglês), nos dois anos que viveu em Paris, entre 1912 e 1916.

Se pensarmos na figura bíblica de Salomé, que tanto fascinou Wilde, encontraremos nos escritos de Mário o mesmo fascínio pelo bailado, personificado na personagem cuja dança dos véus é reproduzida num episódio d'A confissão de Lúcio e transformada no poema Salomé. Mas encontraremos mais. Encontraremos uma alusão ao desvio que Wilde imprime à sua versão da história, na qual introduz uma cena de necrofilia, com a moça beijando os lábios da cabeça decepada de João Batista, cena que também é sugerida no poema de Mário:

Insônia roxa. A luz a virgular-se em medo, Luz morta de luar, mais Alma do que a lua... Ela dança, ela range. A carne, álcool de nua, Alastra-se pra mim num espasmo de segredo...

Tudo é capricho ao seu redor, em sombras fátuas... O aroma endoideceu, upou-se em cor, quebrou... Tenho frio... alabastro!... a minha alma parou... E o seu corpo resvala a projetar estátuas...

Ela chama-me em Íris. Nimba-se a perder-me, Golfa-me os seios nus, ecoa-me em quebranto. Timbres, elmos, punhais... a doida quer morrer-me;

Mordoura-se a chorar - há sexos no seu pranto... Ergo-me em som, oscilo, e parto, e vou arder-me Na boca imperial que humanizou um Santo...

${ }^{1}$ SÁ-CARNEIRO, 1995, p. 77. 
Tanto a obra de Oscar Wilde como a de Mário de Sá-Carneiro revelam o fascínio de seus autores pelo escândalo, além de sua notória inclinação pela escrita autobiográfica. O tema da homossexualidade assume vários desdobramentos: desde a provável confissão de um desejo real, castrado pelo meio repressor; até a metáfora do amor improdutivo, do amor que contraria o propósito burguês da constituição da família e da preservação do patrimônio, base do mundo "lepidóptero" que Mário renegava e que Wilde ironizava.

Mas o tópico que pretendo analisar aqui refere-se mais ao deslumbramento narcísico de ambos os autores com suas próprias imagens, o que também parece justificar a busca do amor homoerótico o amor pelo Mesmo e não pelo Outro -, que seus textos tão insistentemente evocam.

A título de curiosidade, percebe-se que os poetas guardam certa semelhança física. Basta observar suas fotografias, desde as mais antigas, de infância, até as da juventude. O formato do rosto, dos olhos, a pose de dândi, o ar blasé. Estão ambos acima do peso, o que absolutamente não incomoda Wilde, do alto dos seus quase 1,90 m de altura e de sua bem resolvida auto-imagem, mas que se torna a razão da obsessiva negação de Mário sobre a sua própria figura e um dos temas principais de sua poesia.

Também partilham o gosto pelo supérfluo, pelo decorativo, pelas cores e pelas texturas. Wilde cria para si mesmo a profissão de "esteta", viajando pelo mundo para ministrar conferências sobre moda e decoração de ambientes. Mário afunda no luxo "zebrante" dos interiores de sua poesia, nas sedas e brocados de versos que celebram a futilidade de polir as unhas e de degustar licores excessivamente doces e de cores fortes. 

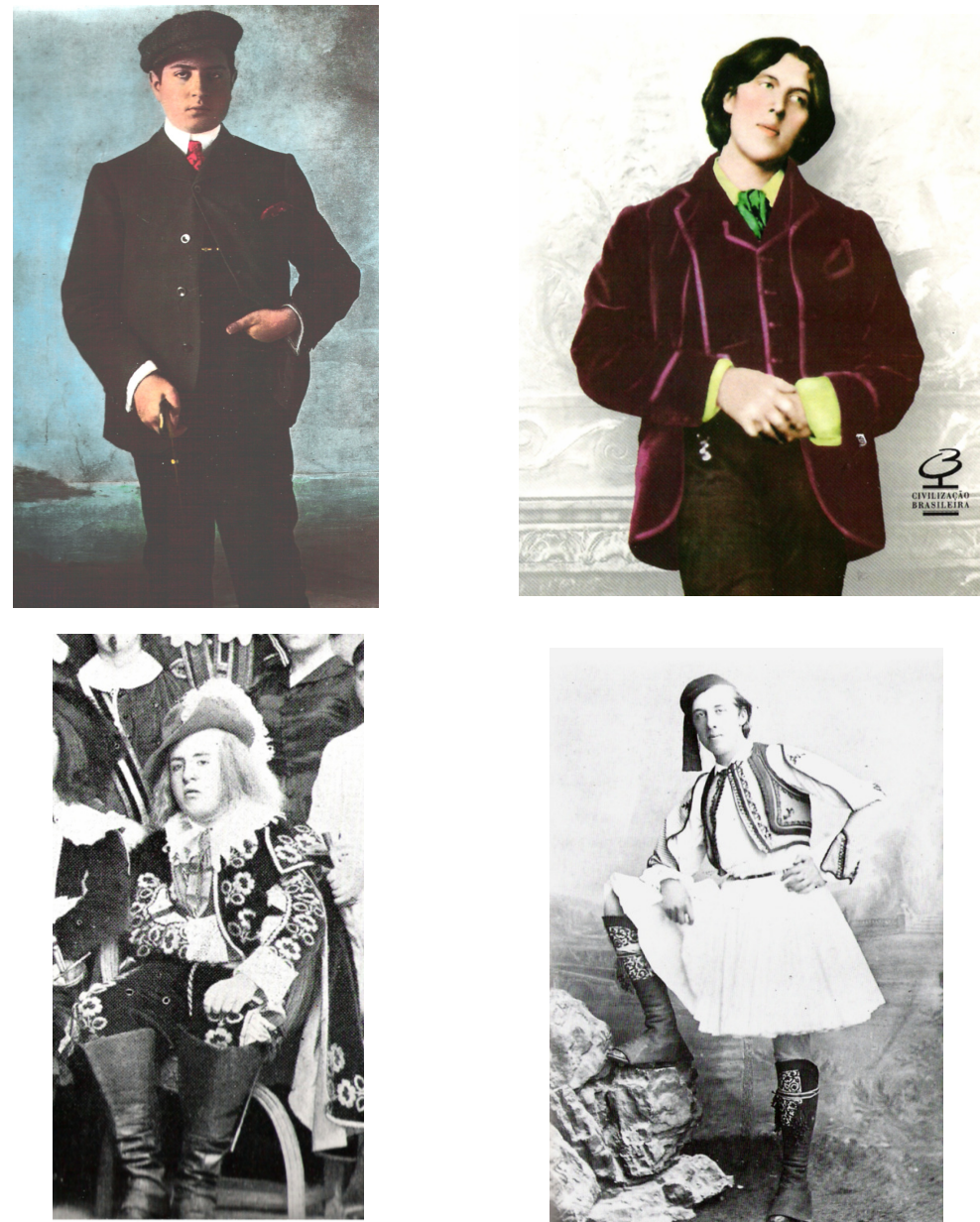

Mário de Sá-Carneiro

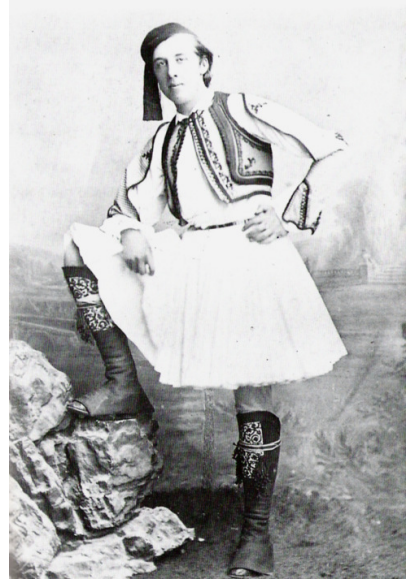

Oscar Wilde

A similaridade que se encontra no exotismo de suas preferências estéticas também aparece em outros aspectos de suas obras. São evidentes, por exemplo, os traços de premonição que elas oferecem sobre os seus destinos igualmente apoteóticos, aos quais alguns críticos mais severos atribuem grande parte do sucesso que alcançaram após a morte. De fato, se não se constituíram a causa, não há como negar que as suas apoteoses pessoais ofereceram um bom motivo para a divulgação de seus textos. 
No caso de Wilde, refiro-me ao escandaloso processo ao qual se lançou de modo impulsivo e temerário, e do qual resultou a sua condenação por crime de natureza sexual devido ao seu relacionamento com o jovem "Bosie", que o levaria à falência, ao ostracismo e, após os dois anos de prisão, à morte em conseqüência das complicações de uma infecção contraída no cárcere.

No caso de Sá-Carneiro, refiro-me ao teatral suicídio encenado por ele num elegante hotel em Paris, com direito a traje a rigor e testemunha convidada para presenciar o drink final de estricnina, além da série dos "Últimos Poemas", onde cria o coro da pantomima circense que projetou para o seu Fim:

Quando eu morrer batam em latas, Rompam aos saltos e aos pinotes Façam estalar no ar chicotes, Chamem palhaços e acrobatas.

Que o meu caixão vá sobre um burro

Ajaezado à andaluza:

A um morto nada se recusa,

E eu quero por força ir de burro... ${ }^{2}$

No “Álbum de Confissão”, preenchido por Wilde em 1877, há previsões perturbadoras sobre a sua própria história. Quando indagado sobre "qual a sua idéia de felicidade", responde: "poder absoluto sobre as mentes humanas". Sua idéia de "miséria", por outro lado, era "viver uma vida pobre e respeitável numa vila obscura, ser um deão esquálido de Oxford". Já a sua resposta para "qual o seu objetivo na vida" é: "O sucesso. De uma forma ou de outra, serei famoso, e, se não famoso, terei notoriedade". ${ }^{3}$

Não surpreende, portanto, que faça o cínico Lord Henry Wotton, reconhecidamente seu alter-ego n'O retrato de Dorian Gray, afirmar, criticando o pintor Hallward por sua excessiva seriedade: "Que homens mais esquisitos são vocês, os artistas! Removem o mundo para adquirir fama. Quando o conseguem, parecem querer atirá-la fora. É uma tolice da sua parte, pois só há no mundo uma coisa pior do que falarem de nós; é não falarem de nós." ${ }^{4}$

\footnotetext{
2 SÁ-CARNEIRO, 1995, p. 131.

3 WILDE, em HOLLAND, 2000, p. 44-45.

${ }^{4}$ WILDE, 2003, p. 51.
} 


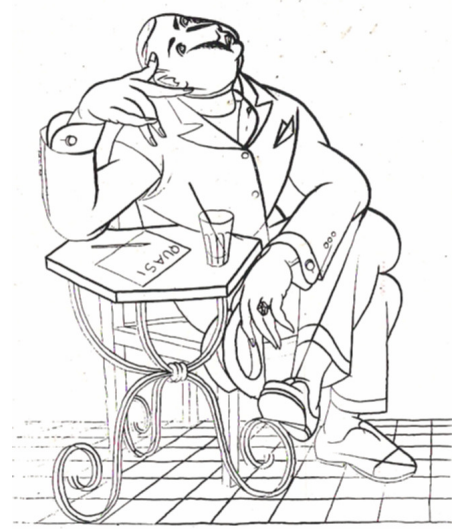

Caricatura de Sá-Carneiro, por Almada Negreiros

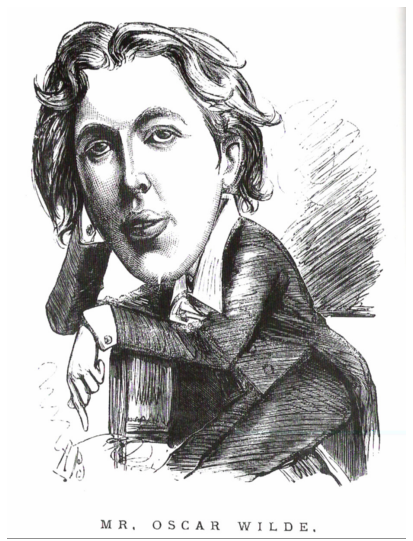

Caricatura de Wilde, por Alfred Bryan

Uma das últimas obras de Oscar Wilde, a longa carta De profundis, escrita para Lord Alfred Douglas, o "Bosie", traz o mesmo tema d'A confissão de Lúcio, de Mário de Sá-Carneiro, embora num tom amargurado. Nesta carta, escrita na prisão, como a novela do português, Wilde se defende, fornecendo detalhadamente os elementos, muitas vezes ambíguos e duvidosos, da sua inocência no processo. São, ambos os textos - o real e o ficcional - "confissões" contra outros, em benefício de seus próprios autores. Como faz o personagem Ricardo de Loureiro ao disparar sua arma contra a pessoa a quem amava para salvaguardar seu orgulho ferido, Wilde, atirando sua mágoa e mesquinharia contra Bosie, já anunciava o seu próprio suicídio. É ele mesmo o maior atingido por suas palavras, e é ele que vemos jazer, derrotado, no final da "confissão".

Da mesma maneira, poderíamos ler n'O retrato de Dorian Gray o grande drama da inaceitação física de Mário de Sá-Carneiro, que o leva a projetar-se na literatura em sucessivos desdobramentos, tornando-se tema de uma poesia que se pode considerar menos autobiográfica do que um auto-retrato literário, já que não estabelece, como nos relatos autobiográficos, um pacto com o leitor implícito. É conhecida a sua autodefinição: "Eu não sou eu nem sou o outro/sou qualquer coisa de intermédio:/pilar da ponte de tédio/que vai de mim para o Outro". 5

${ }^{5}$ SÁ-CARNEIRO, 1995, p. 82. 
Ao contrário dos relatos autobiográficos, o auto-retrato não se dirige a ninguém além do próprio retratado; ele se fecha em si mesmo, como Dorian Gray na auto-contemplação de seu retrato num quarto fechado a sete chaves, onde afunda em comiseração pela consciência de sua dupla imagem, a positiva e a negativa, incompatíveis, jamais coincidentes, porém condenadas a uma coabitação incômoda, perturbadora, inaceitável. É a sensação de ser duplo que leva Dorian, finalmente, ao gesto desesperado de rasgar o retrato, semelhante ao gesto suicida de Mário de Sá-Carneiro.

Sobre as premonições deste suicídio tive a oportunidade de refletir mais demoradamente na minha tese de doutorado, A Mensagem e a Imagem: literatura e pintura no primeiro modernismo português, onde considero que a atração de Mário pelo poeta Fernando Pessoa foi uma atração entre pólos opostos, assim como a sua repulsão por Guilherme de Santa-Rita, seu conterrâneo em Paris, pintor e também colaborador da revista Orpheu, foi uma repulsão entre pólos idênticos. ${ }^{6}$ Ao contrário de Sá-Carneiro e de Santa-Rita Pintor, Pessoa parecia ter opiniões bastante definidas sobre a celebridade, que justificariam o seu "ocultamento" voluntário ao longo da vida:

A celebridade é um plebeísmo. Por isso deve ferir uma alma delicada. É um plebeísmo porque estar em evidência, ser olhado por todos inflige a uma criatura delicada uma sensação de parentesco exterior com as criaturas que armam escândalo nas ruas, que gesticulam e falam alto nas praças. O homem que se torna célebre fica sem vida íntima: tornam-se de vidro as paredes da sua vida doméstica; é sempre como se fosse excessivo o seu traje; e aquelas suas mínimas ações ridiculamente humanas às vezes - que ele quereria invisíveis, coa-as a lente da celebridade para espetaculosas pequenezes, com cuja evidência a alma se estraga ou enfastia. É preciso ser muito grosseiro para se poder ser célebre à vontade.

Por isso, e apesar de sua grande amizade por Sá-Carneiro, Pessoa é muito duro na sua crítica a um certo aspecto "suicida" que o modernismo incensou, ao proclamar a gratuidade de todas as ações e a permissividade de todos os sentimentos, assim como o descompromisso do artista para com o seu trabalho, o que vale tanto para o amigo que desistiu de viver como para o amigo que mandou queimar a própria obra:

\footnotetext{
${ }^{6}$ FERREIRA, 1998.

${ }^{7}$ PESSOA, 1986, p. 502.
} 
Esses moribundos acróbatas conseguiram tornar a morte cômica e a coragem repugnante. É preciso todo o nosso tradicional uso do respeito para ter pena de loucos e de loucos vãos ainda por cima. Seu fim une o suicídio sem patético e a tragédia sem dignidade. ${ }^{8}$

No entanto, apesar de Sá-Carneiro considerar Santa-Rita seu "inimigo íntimo", alguém cujas "pequeninas janelas abertas na sua vida, nos seus pensamentos, fazem-me ver unicamente: hipocrisia, mentira, egoísmo e cálculo, cujo somatório é este: todos os meios são bons para chegar ao fim" (como confessa em suas cartas a Pessoa); e de Santa-Rita também desprezar o poeta, como se percebe em declarações do tipo: "Voulhe dizer uma coisa desagradável. É que você não tem valor para fazer coisas tão belas como essas", ${ }^{10}$ uma estreita sintonia parece ter-se estabelecido entre os dois, identificando seus propósitos estéticos de uma maneira mais real, ainda que menos evidente, do que a que se observou entre os demais componentes da chamada geração de Orpheu.

Uma tal proximidade terá sido decisiva para a introdução do modernismo na literatura portuguesa, sobretudo por um elemento marcante de suas vidas e obras que parece torná-los representantes, já no início do século XX, e ao lado de Oscar Wilde, de uma faceta da modernidade em arte seguramente mais tardia, dominante apenas depois dos anos 50, e que faria destes artistas surpreendentes precursores do pós-modernismo, pelo menos num aspecto: o da supremacia do ego sobre a obra.

É verdade que este aspecto já estaria implícito nos princípios do futurismo, movimento contemporâneo dos dois jovens portugueses. No entanto, não consta que, apesar de sua violência panfletária, de seu culto à revolta e à destruição, Marinetti tenha jamais queimado um museu ou uma biblioteca. O futurismo viveu da propaganda, de um entusiasmo deslumbrado com o progresso, de manifestos programáticos, de idéias. Idéias herdadas de um passado distante, idéias que deixaram herança para o futuro.

Ao contrário de Oscar Wilde, porém, perfeitamente integrado no universo do le monde artístico - o que significava, como diz Tom Wolfe em A palavra pintada, ${ }^{11}$ ser notado, ser reconhecido, ser considerado

\footnotetext{
${ }^{8}$ PESSOA, 1986, p. 501.

${ }^{9}$ SÁ-CARNEIRO, 1995, p. 731.

${ }^{10}$ SÁ-CARNEIRO, 1995, p. 731.

${ }^{11}$ WOLFE, 1987, p. 18.
} 
parte integrante de uma comunidade, ter o seu trabalho, ou a negação dele, comentada e discutida, para o bem ou para o mal (vejam-se os artigos e a coleção de charges de que era alvo na imprensa por todos os lugares onde andava) -, Sá-Carneiro e Santa-Rita viveram em permanente contradição, num universo virtual situado entre a realidade e o desejo: participaram solitariamente, à distância, da atmosfera modernista, mas estiveram excluídos de seus quadros programáticos - atrasados demais em Paris e avançados demais em Portugal -, e abortaram inúmeros projetos.

Ao morrer, aos 30 anos, Santa-Rita exigiu que os parentes queimassem seus quadros, como recomendava o credo da escola futurista. Mário foi mais além, cometendo o suicídio aos 26 anos. Suas ações, que não revelam nenhuma fé, esperança ou entusiasmo no porvir, nascem, talvez, de uma experiência profundamente negativa e do agudo sentimento de estarem à margem do le monde parisiense, que reforçava tanto uma antiga sensação de inadequação, partilhada por ambos em suas histórias pessoais de orfandade e abandono materno; quanto aquela sensação atávica portuguesa, que Eduardo Lourenço tão bem identifica como um misto de fanfarronice e humildade. ${ }^{12}$

O poema Caranguejola, de Mário, expressa com ironia a crise advinda da sensação de isolamento e do seu não reconhecimento como poeta, o que o impede de assumir uma postura mais independente e madura em seu meio:

Noite sempre pelo meu quarto. As cortinas corridas, E eu aninhado a dormir, bem quentinho - que amor... Sim: ficar sempre na cama, nunca mexer, criar bolor Pelo menos o sossego completo... História! Era a melhor das vidas...

Desistamos. A nenhuma parte a minha ânsia me levará.

Pra que hei-de então andar aos tombos, numa inútil correria? Tenham dó de mim. Côa breca! Levem-me pra enfermaria Isto é: pra um quarto particular, que o meu Pai pagará. Justo. Um quarto de hospital - higiênico, todo branco, moderno e tranqüilo;

Em Paris, é preferível - por causa da legenda...

Daqui a vinte anos a minha literatura talvez se entenda E depois estar maluquinho em Paris, fica bem, tem certo estilo... ${ }^{13}$

\footnotetext{
${ }^{12}$ LOURENÇO, 1991. p. 79.

${ }^{13}$ SÁ-CARNEIRO, 1995, p. 125.
} 
Mário de Sá-Carneiro admirava secretamente a aparência física de Santa-Rita Pintor, menos no seu aspecto real, e mais na sua impressão geral de magreza doentia, recoberta por roupas de uma artificialidade e criatividade que o tornavam "diferente", um "esteta" à maneira de Oscar Wilde. Também admirava a facilidade, para o padrão português, com que Santa-Rita circulava, ou dizia circular, no meio artístico, conhecendo gente importante e figuras de ponta, como Pablo Picasso, de quem se dizia amigo.

Tanto é que chega a homenageá-lo francamente numa caricatura literária - o personagem Gervásio Vila-Nova, de A confissão de Lúcio-, e, talvez, no belo e misterioso homem "de rosto esguio e macerado, e cabelos longos aos anéis", sobre o qual confessa Mário no conto "Eu próprio o Outro": "Aquele sim, aquele é que me saberia ser". Essa admiração também se professa em suas idéias estéticas - o que se pode intuir pela dedicação a Santa-Rita do conto "O fixador de instantes", e, no segundo número de Orpheu, dos "Poemas sem suporte a Santa-Rita Pintor": "Elegia", "Manucure" e "Apoteose". Embora disfarçada por afirmações contraditórias, parece haver em Sá-Carneiro um certo e paradoxal impulso de "não realização", efetivamente levado a cabo pelo pintor na sua, por assim dizer, "não-obra".

Pesam contra esta suposição, à parte a evidência da obra realizada, obviamente, os freqüentes testemunhos epistolográficos de Sá-Carneiro ao amigo Pessoa - no qual sempre buscou desesperada e infrutiferamente mais do que uma referência, um mestre -, responsáveis por observações tão contraditórias como: "Eu que sou só cérebro ..."; "Para mim, que só dou valor à obra", e "Vê você que em face de suas poesias eu me limito a distinguir o que acho mais belo. É que o meu espírito não é como o seu, um espírito crítico"; "Eu verifico, perante você, a minha inferioridade. Sim, meu querido amigo, você é a Nação, a Civilização, e eu serei a Grande Sala Real, atapetada e multicolor, a cetins e esmeraldas, em douraduras e marchetações". ${ }^{14}$

Também é curioso como nas cartas a Pessoa, Sá-Carneiro parece não só submisso e humilde, mas muitas vezes insincero, numa evidente ânsia de satisfazer as pressentidas expectativas do outro, isto implicando em enfatizar a suposta diferença de suas opiniões para com as de SantaRita:

${ }^{14}$ SÁ-CARNEIRO, 1995, p. 893. 
É que, segundo o Santa-Rita confessa, para ele vale muito mais o Artista do que as suas obras, isto é: o aspecto exterior do artista, os seus cabelos, os seus fatos, as suas conversas, as suas blagues - o seu eu, em suma, como coisa primordial - a sua obra, como coisa secundária. Isto é espantoso, mas é assim. De forma que a minha obra cubista não era digna de mim... É claro que lhe agradeci a frase, pois ela (para mim, que só dou importância à obra) era um simples elogio. ${ }^{15}$

O conteúdo de sua obra, porém, contradiz essa postura indignada que exibe a Pessoa. Consideremos o conto "Asas", do livro Céu em fogo, por exemplo. Nele, Sá-Carneiro discute detalhadamente os processos de criação e os objetivos estéticos do admirável poeta Petrus Ivanowitch Zagoriansky, cujo grande objetivo como artista era realizar uma "arte fluida, uma arte gasosa ... uma arte sobre a qual a gravidade não tenha ação", objetivo que é, afinal, alcançado pelo desaparecimento da obra: 'Todos os meus versos, libertos enfim, tinham resvalado do meu caderno - por vôos mágicos!'... Sobrava-lhe o caderno, intacto, com as folhas brancas, e no frontispício - detalhe imprescindível - "o nome do Poeta". ${ }^{16}$

Estava concluída, em tese, uma obra de inspiração santa-ritina, nem exatamente cubista nem futurista, mas francamente, absurdamente, pósmoderna. Um exemplo como tantos outros que hoje, freqüentemente, substituem o espaço da antiga Arte, flutuando na insustentável leveza de seus produtores, espelhando-os, promovendo-os, projetando-os numa já desgastada ânsia de novidade e de escândalo, onde a obra conta menos que o artista e onde a mensagem conta menos que a imagem. Estavam traçados os princípios de uma atitude que nem Santa-Rita nem SáCarneiro poderiam, à sua época, supor que se tornaria a marca da nossa contemporaneidade. Sem o saber, estavam ambos inteiramente perdidos, completamente seduzidos por aquilo que Donald Kuspit, em seu livro $O$ culto do artista de vanguarda, viria a identificar como "o carisma do cinismo" da arte pós-moderna.

Produtos supremos de uma das mais marcantes características postas em funcionamento pelos movimentos da modernidade, SáCarneiro e Santa-Rita, assim como Oscar Wilde, expressaram em suas vidas performáticas uma ambição que transcendia seu próprio tempo, que

\footnotetext{
${ }^{15}$ SÁ-CARNEIRO, 1995, p. 784.

${ }^{16}$ SÁ-CARNEIRO, 1995, p. 483.
} 
transcendia mesmo a ambição autobiográfica - onde, como já se observou, a busca da fama decorrente da afirmação do sujeito através de um estilo, que é propriamente "moderna", converte-se na ambição do auto-retrato, da celebridade, que é tipicamente "pós-moderna". Para Donald Kuspit a fama não se confunde com a celebridade:

\begin{abstract}
Alguém fica famoso por encontrar, explorar e compreender, com profundidade, certo aspecto do real, enquanto alguém fica célebre quando consegue elaborar sua própria imagem de tal modo que ela se torne narcisisticamente satisfatória para os outros tanto quanto para si mesmo. A sociedade moderna, ao encorajar a procura da fama, pressupõe que o risco é a essência da vida. A descoberta da profundidade perturba o status quo da sociedade e do indivíduo. A sociedade pós-moderna, ao encorajar a celebridade através da teatralização do indivíduo, revela sua determinação narcisista de manter o status quo social. ${ }^{17}$
\end{abstract}

No caso dos artistas considerados, é certo que o pendor para tornar-se uma celebridade aproxima muito mais a figura de Santa-Rita do que a de Mário dos princípios estéticos de Oscar Wilde. É quase unânime a opinião dos críticos sobre o seu egocentrismo, megalomania e narcisismo. Tais características teriam influenciado, no pintor português, a substituição da obra pelo exibicionismo do sujeito, levando-o a converter a sua curta vida num vertiginoso happening, numa calculada propaganda de si mesmo, voltada à elaboração de um auto-retrato não traçado com tintas e pincéis, mas com acontecimentos: um auto-retrato vivo, portanto, garantia de um nome e de uma imagem pessoal que pudesse preencher ou substituir a ausência de uma produção qualquer, à qual, de resto, não creditava um valor de permanência. A este respeito, diz Bernardo Pinto de Almeida:

Santa-Rita sabia, ou intuía, a força das imagens num mundo que brevemente haveria de ser dominado por elas. Para o manifestar, conseqüentemente, escolheu a que lhe terá parecido mais digna de constituir a mais radical e verdadeira ameaça, e que, ao mesmo tempo, lhe servia a febre megalómana: a sua própria imagem. ${ }^{18}$

17 KUSPIT, 1995, p. 72.

${ }^{18}$ ALMEIDA,1994. p. 336. 
Já o caso de Sá-Carneiro se afigura mais problemático, pela própria existência de uma obra poética e narrativa bastante rica, sobretudo se considerarmos o breve período de tempo em que foi realizada. Mas se analisada de perto - e isto também costuma ser um ponto pacífico entre os críticos - trata-se de uma obra que espelha a vida, falho o distanciamento entre verdade e ficção no que se refere ao sujeito: a ficção refletindo a vida real ou idealizada, a vida real reproduzindo assustadoramente a ficção.

Constantemente remetendo à sua obra, as cartas de Sá-Carneiro, sobretudo as escritas a Fernando Pessoa, induzem o leitor a um inesgotável confronto entre o que é narrado e o que é vivido. Seus estados de ânimo confundem-se com os de seus personagens, os fatos de sua vida transformam-se em poemas, de tal forma que a literatura parece contribuir mais para inscrevê-lo na realidade do que para traduzir uma qualquer realidade. Através das cartas é possível acompanhar o longo preparo de um glorioso ápice existencial, cuidadosamente planejado no decorrer dos anos, e com desdobramentos tão misteriosos e intrigantes como os desfechos cultivados em sua ficção de tendência gótica, ou ainda mais. Mutuamente iluminadas, correspondência e obra denunciam, assim, o que poderia ser considerado a crônica de um suicídio anunciado, debatido, estudado, sonhado e ensaiado. Mas com que objetivos?

Um elemento marcante encontrado em muitas de suas narrativas talvez possa fornecer uma pista para suposições a este respeito, com a cautela que é necessária nesses casos, pois não é possível saber realmente as verdadeiras razões que movem as pessoas a atitudes extremas como esta, e mesmo num autor de forte pendor auto-referencial não se pode confundir a vida com a ficção. No entanto, não é possível negar a presença, sobretudo em alguns contos, de uma ânsia de reconhecimento, de sucesso, de rápida fama, transferida para certos personagens que agem conforme o que Sá-Carneiro condenava em Santa-Rita como uma falta de ética.

É o que se observa, por exemplo, num episódio relatado no conto "A grande sombra". Trata-se do suicídio de um certo companheiro, um ato gratuito, feito mais para impressionar os amigos a quem o suicida teria confessado motivos diversos e teatralizado razões para a sua morte, a essa altura inteiramente banalizada. Chama a atenção, além do completo desprezo generalizado para com a vida, o cuidado fútil com a descrição da vestimenta do sujeito (que seria semelhante à usada pelo autor quando do seu próprio suicídio): "impecável e risonho, de smoking, e nova flor 
na lapela, uma grande rosa vermelha" e a admiração do narrador diante da atitude do personagem: "Seja como for, criaturas assim aureolizam efetuar-se um pouco em mistério - esbatem-se em Asas, ungem-se de Errado... São, pelo menos, maiores do que eu...". ${ }^{19}$

Mas é o brevíssimo conto "Ladislau Ventura" que melhor traduz este aspecto, pois trata especificamente de um suposto poeta, um "apaixonado pelas letras" cuja "única ambição era a glória e a celebridade". Para as alcançar "não recuaria diante de nenhum obstáculo". Todos os elementos estão aí presentes: o desprezo para com a obra: “...em três ou quatro meses manufaturou dois novos dramas e três novos romances, enviouos pelos correios a um livreiro"; o descaso para com a vida, dele e dos outros, em face da possibilidade do sucesso rápido, que o leva a forjar um caso de amor impossível, assassinando uma famosa atriz durante um espetáculo e suicidando-se a seguir, conseguindo através da publicidade atingir o seu intento: "Pouco tempo depois, os teatros anunciavam as peças do 'poético criminoso' e as livrarias os romances do 'terrível amoroso'. Que magnífico reclamo!! As edições esgotaram-se, os teatros encheramse e hoje ninguém desconhece o nome de Ladislau Ventura...". ${ }^{20}$ Em "Página dum suicida", o autor ensaia uma explicação para essa inegável atração pelo espetáculo da autopromoção a qualquer preço:

Afinal, sou simplesmente uma vítima da época, nada mais... O meu espírito é um espírito aventuroso e investigador por excelência. Se eu tivesse nascido no século XV descobriria novos mares, novos continentes... No começo do século XIX teria inventado talvez o caminho de ferro... Há poucos anos, mesmo, ainda teria com o que me ocupar: os automóveis, a telegrafia sem fios... Mas agora... agora que me resta?... A aviação?... Pf.... essa já nada me interessa... Não há dúvida: a única coisa interessante que existe atualmente na vida é a morte!... Pois bem, serei eu o primeiro explorador dessa região misteriosa, completamente desconhecida... ${ }^{21}$

Ao lado da ironia melancólica que permeia esse texto, há realmente um paradoxal entusiasmo que terá movido o autor a buscar na teatralização da morte uma motivação para a sua obra e a sua vida. Seus

${ }^{19}$ SÁ-CARNEIRO, 1995, p. 419.

${ }^{20}$ SÁ-CARNEIRO, 1995, p. 600.

${ }^{21}$ SÁ-CARNEIRO, 1995, p. 263. 
contos são histórias de grande vaidade, uma vaidade sem limites que inverte os valores até então considerados predominantes na existência, como a própria existência. A consistência do que se faz, a fama decorrente da obra - e não o inverso - tudo isso já parece ultrapassado no código de valores de Sá-Carneiro.

Entre Sá-Carneiro e a ética do nosso tempo de hiper-realismo e superexposição há um abismo de quase um século, embora pouca evolução em "qualidade". Poder-se-ia arriscar que, tal como seus personagens, Sá-Carneiro sacrifica-se apoteótica e radiosamente pela projeção de seu nome. Sabe - ou espera - que após este gesto será conhecido e lembrado como não seria, talvez, sem o suicídio, que afinal é uma marca de diferença, excentricidade, num certo sentido até mesmo de coragem, exemplo máximo de desprezo pelos "lepidópteros" do mundo dos quais desejava ardentemente distanciar-se.

Sob um certo aspecto, Sá-Carneiro projeta-se menos pelo que produz do que pelo que se decide a fazer, no momento culminante para o qual viveu e escreveu. Experimentando, por antecipação, o sentimento de desreferencialização de um real que se degrada em fantasmagoria, e de dessubstancialização do sujeito que passa a ser secundário e subalterno diante dos objetos; tendendo para a desvalorização da vida, para a banalização da morte, do crime, da violência e da dor, Sá-Carneiro age menos como o romântico decadentista que finge ser em seus poemas, menos como o sensacionista ou o cubofuturista que finge ser em sua vida, e mais como um pós-moderno.

Há, na sua obra, evidentes sinais de sadomasoquismo, cenas eróticas que se misturam com perversões e torturas, espetáculos de violência hiper-realista, num estilo talvez demasiado hard para um jovem inexperiente do início do século XX, embora bastante previsível num jovem contemporâneo. Pois, como afirma Gilles Lipovetsky, o mundo hard é cada vez mais jovem e a representação da violência nas sociedades pós-modernas torna-se tanto mais exacerbada quando mais se supõe regredir a violência física inter-individual num mundo que se deseja civilizado e cool. ${ }^{22}$

Embora o tom de sua obra faça pensar no decadentismo, há grande diferença entre um Werther, uma Dama das Camélias, um Antony personagens que gosta de citar - e ele mesmo, assim como também falta,

${ }^{22}$ LIPOVETSKY, 1983, p. 190. 
nos ecos modernos de sua produção, a fé empreendedora e a personalidade realmente voltada à aventura revolucionária do início do século. Os suicídios românticos são apoteoses de desistências nobres, heróicas ou trágicas, mas sempre motivadas. O suicídio para Sá-Carneiro, como mostram os suicídios representados em suas obras, é a apoteose de uma insistência perversa ou pervertida, premonição de uma vitória "outra", para a qual prescinde da vida como um não-valor: "Hoje vou viver o meu último dia feliz. Estou muito contente. Mil anos me separam de amanhã... Eu não me mato por coisa nenhuma... acho belo levar comigo alguma coisa que ninguém sabe ao certo, senão eu. Não me perdi por ninguém: perdi-me por mim, mas fiel aos meus versos". ${ }^{23}$

Através do suicídio, e ao contrário do Pessoa-Campos da exclamação "Arre! Vou existir!", ${ }^{24}$ Sá-Carneiro crê, talvez, encontrar uma saída para o que sente ser uma limitação. Carnavaliza e ironiza a si mesmo matando-se - mas em grande estilo, como se o fizesse movido menos por razões de foro íntimo do que pelo absurdo desejo de conferir verossimilhança às palavras escritas em seus últimos poemas.

Em sua análise sobre o suicídio na sociedade individualista contemporânea, Gilles Lipovetsky comenta:

Essa liquefação do desejo de aniquilamento é apenas uma das faces do neo-narcisismo, da desestruturação do Eu e da dessubstancialização da vontade. Quando o narcisismo é preponderante, o suicídio procede mais de uma espontaneidade depressiva, de um flip efêmero do que de um desespero existencial definitivo. Deste modo, em nossos dias, o suicídio pode verificar-se paradoxalmente sem desejo de morte. ${ }^{25}$

Como no conto "Ladislau Ventura", a realidade é construída em função da literatura, e não o contrário. Desta forma, a obra de Sá-Carneiro não parece tão sintonizada com o gênero fantástico, tendência freqüente nas análises de seus textos, mas com algo muito mais atual: o hiper-realismo.

\footnotetext{
${ }^{3}$ SÁ-CARNEIRO, 1995, p. 969.

${ }^{24}$ Trata-se do poema "Bicarbonato de Soda", no qual Álvaro de Campos, em plena crise de depressão, considera o suicídio: "Devo tomar qualquer coisa ou suicidar-me?/Não: vou existir. Arre! Vou existir./E-xis-tir.../E-xis-tir...”. PESSOA, 1986, p. 314.

${ }^{25}$ LIPOVETSKY, 1983, p. 198.
} 
A ficção torna-se mais forte e mais real que a própria realidade. Sá-Carneiro vive e morre num universo virtual, em estado de insustentável leveza.

Ironicamente, é a realidade de seu aspecto físico, o caráter grotesco do peso que carrega em seu corpo o que parece impulsioná-lo a buscar as sensações ilusórias e evanescentes capazes de desprendê-lo do chão ao qual sente-se acorrentado. De fato, a morte não o assustava tanto quanto uma vida obscura, sem luxos, sem vênias, sem Paris. Se pudéssemos ouvir o que teria a dizer do outro lado da existência, talvez nos surpreendêssemos, como nos surpreendemos com as afirmações de Oscar Wilde na carta De profundis. Se considerarmos o grande exibicionista, o alegre esteta do le monde, o performático e entediado dândi das rodas de intelectuais, famoso pelos ditos cínicos e pelas tiradas agudas e demolidoras da moral burguesa, estranharemos ouvir esse verdadeiro ato de contrição:

Começarei por dizer-te que me censuro a mim mesmo terrivelmente. Sentado nesta sombria cela, com traje de presidiário, como um homem arruinado e desonrado me censuro. Durante as noites de angústia, turbulenta e agitada; durante os longos e monótonos dias de dor, a mim é que censuro. Censuro-me por ter permitido que uma amizade não intelectual, uma amizade cujo primordial objetivo não foi a criação e a contemplação de belas coisas, dominasse por completo a minha vida. (...) Necessito dizer a mim mesmo que tenho a culpa de tudo, que ninguém se aniquila senão por sua própria vontade. Estou disposto a reconhecê-lo, embora neste momento não me creiam. Essa acusação cruel atiro-a sem piedade sobre minha conduta. Se terrível foi o que o mundo me fez, muito mais terrível foi o dano que causei a mim mesmo.Estava eu relacionado, de um modo simbólico, com a arte e a cultura de meu tempo. Havia percebido isto no declive de minha vida e havia obrigado meus contemporâneos a aceitá-lo. Poucos homens chegam a alcançar em vida uma posição semelhante à minha. Em geral, são descobertos pelos historiadores e pelos críticos depois que eles e com eles sua época desapareceram. Comigo foi absolutamente diferente. Os deuses tinham sido generosos comigo. Possuía gênio, um nome distinto, uma elevada posição social, brilho e audácia intelectual. Fazia da arte uma filosofia e da filosofia uma arte. Alterava as mentes dos homens e as cores das coisas. Não havia nada que eu dissesse ou fizesse que não maravilhasse as pessoas. Considerei a arte como a suprema realidade e a vida como um simples modo de ficção. Alimentei a imaginação de meu século até criar o mito e a lenda em redor de mim. Divertia-me em ser um flâneur, um dândi, um 
homem da moda. Rodeei-me de pessoas de mentalidade grosseira e malgastei meu talento. Cansado das alturas, baixei ao mais profundo em busca de novas sensações. Deixei, sem suspeitá-lo, de ser dono de mim mesmo e o condutor de minha alma. Permiti que o prazer se apoderasse de mim e terminei na mais espantosa das desgraças. Agora não me resta mais que uma só coisa: a humildade absoluta. ${ }^{26}$

Esse trecho - tão pouco wildiano e ao qual Wilde não se manteria fiel, procurando o Bosie causador da sua desgraça tão logo saiu da prisão, para tentar levar o mesmo gênero de vida, e morrendo logo após ser abandonado pelo amigo que não suportava a sua companhia sem os antigos louros da fama e da fortuna - lembra o compromisso severo e sincero de Pessoa para com a arte acima de tudo. O pesado Pessoa, lembrando aos seus contemporâneos que "Os deuses vendem quando dão/compra-se a honra com a desgraça/ ai dos felizes porque são/ só o que passa"; e insistindo, na sua Mensagem profundamente moral ao futuro, que "Tudo vale a pena/se a alma não é pequena./Quem quer passar além do Bojador/tem que passar além da dor./Deus ao mar o perigo e o abismo deu,/mas nele é que espelhou o céu." ${ }^{27}$

A contradição leve-pesado conduz, por associação, a uma outra, a contradição profundidade versus superficialidade, implícita nos paralelismos tão freqüentemente utilizados na literatura: céu-terra, altobaixo, vôo-queda, esta última de notória preferência nos estudos teóricos sobre Sá-Carneiro. É conhecido o ensaio de David Mourão-Ferreira intitulado "Ícaro e Dédalo: Mário de Sá-Carneiro e Fernando Pessoa", que lançou a bela e convincente imagem do poeta como um Ícaro procurando nas alturas a aventura e o risco, à revelia dos conselhos de seu ponderado mestre, e por isso queimando imprudentemente as asas no céu em fogo, vindo a cair prematuramente. ${ }^{28}$

E, no entanto, a um certo olhar, a verticalidade sobre a qual se baseia esta analogia não parece ser realmente a orientação mais característica da geografia poética de Sá-Carneiro, apesar do que sugerem suas imagens literárias preferenciais. Isto provavelmente porque, assim como para Santa-Rita, o céu para Sá-Carneiro não é o céu dos poetas

\footnotetext{
${ }^{26}$ WILDE, 2003, p. 1389.

${ }^{27}$ PESSOA, 1986, p. 16.

${ }^{28}$ MOURÃO-FERREIRA, em Hospital das Letras.
} 
dantescos e miltonianos: seres privilegiados e inspirados que ascendem ao sagrado e ao sublime através da imaginação e da fantasia. Tampouco é o céu destes seres de aspirações elevadas que são os filósofos: metáfora do pensamento, da atitude racional e lúcida, um céu inteligível que nos distrai menos da terra do que compreende a sua lei.

Para este poeta e este pintor, exilados das formas tradicionais de grandeza e beleza - heró́smo, santidade e genialidade artística, sinônimos de "profundidade" - a noção do céu estaria mais próxima de uma imagem de limite pessoal, um lago invertido onde os narcisos futuristas poderiam experimentar a sensação de se refletirem nas "alturas" sem dispenderem esforços ou correrem riscos desnecessários, como o de afundar e desaparecer nas profundezas do esquecimento. Visto hoje à luz - se é que assim se pode chamar - da pós-modernidade, o céu para eles parece representar tão-somente um espelho onde não buscam nada além de suas próprias imagens.

Sá-Carneiro e Oscar Wilde não estão jamais na natureza, mas em recintos fechados, pesados de adornos, cortinas e tapetes, onde muitos segredos poderiam se esconder... e, no entanto, já não há nenhum segredo. O único céu que parecem ver é o teto - do quarto, do atelier, dos cafés. Não há, pois, aventuras para estes escritores, mas uma aventura de caráter muito específico: sua "ascensão" à superfície, sua desmistificação da falsa profundidade, sua descoberta de que tudo se passa na fronteira.

Como na história de Alice do outro lado do espelbo, de Lewis Carroll, os animais do país das maravilhas dão lugar a figuras de cartas de baralho sem espessura. A antiga profundidade desdobra-se na superfície, converte-se em largura. Explodem, então, os ditos espirituosos que tanto notabilizaram as peças teatrais de Oscar Wilde, assim como, na poesia de Sá-Carneiro, as cores: palavras iluminadas por uma fonte artificial, sem nenhum sentido senão a beleza que evocam, cuja sensualidade à flor da pele tenciona provocar menos o desejo de compreender que o de tocar, inatingível sempre.

Em sua análise sobre a passagem de Alice do "País das Maravilhas" para o "País do Espelho", Gilles Deleuze explica como, nesses casos, o céu passa a não significar, em absoluto, uma altura que seria somente o inverso da profundidade. Na sua oposição com a terra profunda, o ar e o céu são a descrição de uma superfície pura e sobrevôo do campo desta superfície: "O céu solipsista não tem profundidade". O que não significa, porém, pelo menos para Deleuze, um critério negativo. Aliás, ele faz 
questão de ressaltar como um estranho preconceito este que valoriza cegamente a profundidade em detrimento da superfície e que pretende que "superfície" signifique não "de vasta dimensão" mas "de pouca profundidade", enquanto "profundo" signifique, ao contrário, "de grande profundidade" e não de "fraca superfície". ${ }^{29}$

Contrariam, portanto, a visão de Baudelaire, que percebe no poeta moderno, privado deste céu profundo e arrastado para a violência deste extenso chão, uma terrível tragédia, que expressa no poema "O albatroz", na imagem do pássaro capturado e torturado pela ignorância humana:

Às vezes, por prazer, os homens da equipagem Pegam um albatroz, imensa ave dos mares, Que acompanha, indolente parceiro de viagem, O navio a singrar por glaucos patamares.

Tão logo o estendem sobre as tábuas do convés, O monarca do azul, canhestro e envergonhado, Deixa pender, qual par de remos junto aos pés, As asas em que fulge um branco imaculado.

Antes tão belo, como é feio na desgraça Esse viajante agora flácido e acanhado! Um, com o cachimbo, lhe enche o bico de fumaça, Outro, a coxear, imita o enfermo outrora alado!

O Poeta se compara ao príncipe da altura Que enfrenta os vendavais e ri da seta no ar; Exilado no chão, em meio à turba obscura, As asas de gigante impedem-no de andar. ${ }^{30}$

De fato, nem Oscar Wilde nem Sá-Carneiro parecem identificar-se com o triste albatroz baudelairiano. Seus espíritos artísticos, assim como suas obras, não parecem revelar vocação para verdadeiros vôos ou profundos e perigosos mergulhos. Seus interesses concentram-se mais na "vasta dimensão da superfície" - de suas vidas, obras, e, por que não dizer, de seus próprios corpos, objetos de suas reconhecidas preocupações, temas de tantos de seus escritos. Além disso, é evidente que não querem deixar mensagens outras além do eventual registro de suas imagens,

\footnotetext{
${ }^{29}$ DELEUZE, 1974, p. 324.

${ }^{30}$ BAUDELAIRE, 1985, p. 111.
} 
tornadas objetos e temas preferenciais de sua arte. Não querem salvar a ninguém, nem a si mesmos, e nem pensam no poder salvacionista da arte como os demais modernos, ainda quando expressam o contrário.

Daí porque tendem a realizar uma arte pouco natural, pouco comprometida, que celebra justamente a sua artificialidade, sua gratuidade, o seu "erro". Mas na época de Oscar Wilde, e mesmo na de Sá-Carneiro, esta leveza era absolutamente insustentável, sentida como uma incapacidade, uma limitação. Ser "profundo" ainda era uma condição indissociável da ascensão aos andares supremos ou ao céu da sabedoria, da arte, da ciência e do sucesso. Vivia-se ainda toda uma tradição de verticalidade na arte.

O poeta gordo continua, portanto, preso ao seu paradoxo existencial: é um homem pesado, que não se ajusta aos padrões de beleza física modernos, baseados no conceito de leveza, e é dono de uma obra leve, que não se ajusta aos padrões estéticos modernos, baseados no conceito de peso. Não pode ser um homem superficial do le monde, como Oscar Wilde, nem um poeta profundo, como Pessoa. Aventura-se, portanto, no suicídio, que não só lhe rouba o peso do corpo - a insuportável existência em permanente contradição -, como confere certa profundidade aos seus escritos tão auto-referenciais, pela tragicidade teatral imposta à sua história de vida.

Explica-se, ante essa perspectiva, a pertinência da preposição "sobre" no último verso do poema "A queda": "Tombei ... E fico só, esmagado sobre mim"; que tanta discussão tem gerado desde que foi apresentado a Fernando Pessoa. Compreende-se a resistência de Mário em mudá-la para "sob", desfazendo, assim, todo o efeito pretendido. É que os seus versos descrevem uma autêntica, embora paradoxal, "queda para o alto", como fica claro nestes versos, onde o verbo "tombar" - "num grande retrocesso" - é associado a "ascender":

Não me pude vencer mas posso-me esmagar,

- Vencer às vezes é o mesmo que tombar-

E como inda sou luz num grande retrocesso,

Em raivas ideais ascendo até ao fim

$\cdots$

Tombei." ${ }^{\prime 1}$

${ }^{31}$ SÁ-CARNEIRO, 1995, p. 72. 


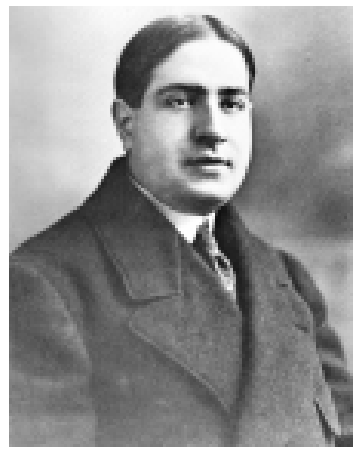

Mário de Sá-Carneiro

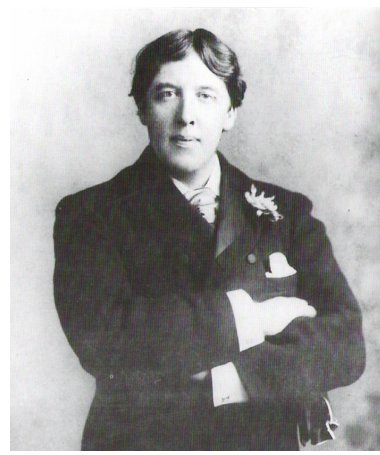

Oscar Wilde

Para Eduardo Lourenço, que também discorda da legitimidade da pulsão ascencional em Sá-Carneiro, "este estranho Ícaro voou em permanência dois vôos opostos e toda a ascensão lhe foi queda, e toda queda ascensão. Não voava em céus ou para céus que não havia. Voava nele mesmo, experimentando na queda aquele pavor fulgurante que remata os pesadelos onde se cai para lado nenhum, infindamente". ${ }^{32}$

Se tivesse vivido cinqüenta anos depois, contudo, Sá-Carneiro não precisaria se matar: "profundo" teria deixado de ser um elogio, como diz Deleuze. O poeta sensível e obeso já não precisaria fingir ser um Ícaro, ou um albatroz: condenação constante a uma queda, anseio de levitação vivido como dor e privação. Poderia então, sem culpa, confessar-se uma "estátua falsa": "Só de ouro falso os meus olhos se douram;/ Sou esfinge sem mistério no poente". ${ }^{33}$ Oscar Wilde, também, não precisaria reforçar o horror que nutria, ou tentava nutrir, pelo impulso que continuamente confessava sentir pela superfície, como o faz em seu poema A esfinge:

Vai-te daqui, repugnante mistério! Horrendo animal, vai-te daqui!

Despertas em mim bestiais sensações, fazes de mim aquilo que eu não quereria ser.

Tornas aquilo em que creio uma estúpida fraude, despertas obscenos sonhos

De vida sensual e Átis e sua faca manchada de sangue eram melhores

\footnotetext{
${ }^{32}$ LOURENÇO, 1990, p. 11.

${ }^{3}$ SÁ-CARNEIRO, 1995, p. 64.
} 
Do que essa coisa que eu sou.

Esfinge falaz! Esfinge falaz! ${ }^{34}$

Poderiam, ambos, reconciliar-se consigo mesmos e com o seu narcisismo, sem culpa, reconhecendo-se, afinal, na Esfinge que Lou Reed e John Cale tecem, no futuro, em homenagem a Andy Warhol, o pintor das celebridades:

I'm no sphinx, no mistery enigma

What I paint is very ordinary

I don't think I'm old or modern

I don't think I think I'm thinking

It does't matter what I'm thinking

It's the images that are worth repeating

Images/Images/Images/Images

If you're looking for a deeper meaning

I'm as deep as this high ceiling.... ${ }^{35}$

Sem a pessoana necessidade de se multiplicar em personalidades menos banais, Wilde e Sá-Carneiro poderiam mesmo fazer coro a Álvaro de Campos em seus pressentimentos tão procedentes, pelo menos no que se refere a essa tendência da arte moderna:

Ver as cousas até ao fundo...

E se as cousas não tiverem fundo?

Ah, que bela a superfície!

Talvez a superfície seja a essência

E o mais que a superfície seja o mais que tudo

E o mais que tudo não é nada.

Ó face do mundo, só tu, de todas as faces,

És a própria alma que refletes. ${ }^{36}$

${ }^{34}$ WILDE, 2003, p. 958.

${ }^{35}$ REED. Songs for Drella. "Eu não sou uma esfinge, um misterioso enigma/O que eu pinto é bem comum/Eu não penso se sou antigo ou moderno/Eu não penso que penso que estou pensando/Não importa o que eu estou pensando/ São as imagens que importa repetir/Imagens, imagens, imagens, imagens/Se você está procurando um significado mais profundo/Sou tão profundo quando este teto alto...".

${ }^{36}$ PESSOA, 1986, p. 352. 
O que as obras de Oscar Wilde e de Sá-Carneiro revelam, afinal, é a opção por uma "horizontalidade" poética, onde o duplo sentido da superfície, a continuidade do avesso e do direito substituem a altura e a profundidade, transformadas em imagens reincidentes e problemáticas em seus textos. Em seus versos e narrativas já não há nada atrás da cortina, salvo misturas inomináveis, nada acima do tapete, salvo o céu vazio. Como diz Deleuze, "o sentido aparece e atua na superfície, de maneira a formar letras de poeira ou como um vapor sobre um vidro em que um dedo pode escrever". ${ }^{37}$ Explica o poeta: "É que há Arte que se aprecia melhor antes de se procurar compreendê-la. Pressentir é mais que sentir".

E eu me pergunto: será mesmo?...

A impressão atual que se tem, muitas vezes, das conseqüências dessa atitude suicidária do sentido, incensada sobretudo ao longo do século XX, é a de que vivemos um equívoco alarmante. Segundo Afonso Romano de Sant'Anna, que discute o problema em seu livro Desconstruir Duchamp,

a representação do suicídio do sujeito na arte levou a um progressivo suicídio da própria arte, resultante talvez de um trauma que ficou na memória do Ocidente, pelo fato de vários artistas recusados em salões oficiais, repudiados publicamente ou mesmo condenados à prisão no final do século XIX terem posteriormente sido aceitos como alguns dos maiores criadores de seu tempo. Desde então, a possibilidade de que nossos conceitos de arte estejam equivocados e que sejamos tidos no futuro como incompetentes e ignorantes para perceber a vanguarda e o novo fez com que se abrissem, ou melhor, que se escancarassem as portas do julgamento estético. Desse modo, passou-se a aceitar como arte tudo aquilo que o artista ou alguém por ele apresenta como obra de arte. Passou a valer a assinatura e a intenção. Daí, um silogismo perverso: se tudo é arte, nada é arte. ${ }^{38}$

Marcel Duchamp resume muito bem o estado atual das artes, quando diz: "Joguei o urinol na cara deles como um desafio e agora eles o admiram como um objeto de arte por sua beleza." Por isso, concordo com Sant'Anna quando diz que "a melhor homenagem que podemos fazer aos mestres contestadores de ontem é contestá-los hoje. Não para que a arte volte ao passado, mas para que ela se possibilite no futuro". ${ }^{39}$ As questões éticas

\footnotetext{
${ }^{37}$ DELEUZE, 1974, p.325.

${ }^{38}$ SANT'ANNA, 2003, p. 17.

${ }^{39}$ SANT'ANNA, 2003, p. 76.
} 
e estéticas levantadas por Mário de Sá-Carneiro e Oscar Wilde em suas obras, permeadas de dúvidas e de ironia, e espelhadas nos conflitos por eles vivenciados em suas próprias vidas, sugerem que o tema da supremacia do ego sobre a arte demanda urgente revisão.

\section{Referências Bibliográficas}

ALMEIDA, Bernardo Pinto de. Espelhos de atelier. In: Orosto da máscara. Autorepresentação na arte portuguesa. Lisboa: Centro Cultural de Belém, 1994.

BAUDELAIRE, Charles. As flores do mal. Edição bilíngüe. Trad. Ivan Junqueira. Rio de Janeiro: Nova Fronteira, 1985.

DELEUZE, Gilles. Lógica do sentido. São Paulo: Perspectiva, 1974.

DIAS, Marina Tavares. Mário de Sá-Carneiro: fotobiografia. Lisboa: Quimera, 1988.

FERREIRA, Ermelinda Maria Araújo. A Mensagem e a Imagem: literatura epintura no primeiro modernismo português. 1998. Tese (Doutorado) - PUC-Rio, Rio de Janeiro.

HOLLAND, Merlin. O álbum de Oscar Wilde. Rio de Janeiro: Civilização Brasileira, 2000.

KUSPIT, Donald. The cult of the avant-garde artist. New York: Cambridge University Press, 1995.

LIPOVETSKY, Gilles. A era do vazio. Ensaio sobre o individualismo contemporâneo. Lisboa: Relógio D’Água, 1983.

LOURENÇO, Eduardo. O labirinto da saudade. Lisboa: Dom Quixote, 1982.

Suicidária modernidade, em: Colóquio Letras, n. 117/118, Set/Dez 1990.

MOURÃO-FERREIRA, David. "Ícaro e Dédalo: Mário de Sá-Carneiro e Fernando Pessoa", em: Hospital das Letras.

PESSOA, Fernando. Obra poética - volume único. Seleção, organização e notas: Maria Aliete Galhoz. Rio de Janeiro: Nova Aguilar, 1986.

Obras em prosa - volume único. Organização, introdução e notas: Cleonice Berardinelli. Rio de Janeiro: Nova Aguilar, 1986.

SÁ-CARNEIRO, Mário de. A confissão de Lúcio (novela); Poesia; Contos; Correspondência, em: Obra Completa-volume único. Introdução e organização: Alexei Bueno. Rio de Janeiro: Nova Aguilar, 1995. 
SANT'ANNA, Affonso Romano de. Desconstruir Duchamp. Arte na hora da revisão. Rio de Janeiro: Vieira \& Lent, 2003.

WILDE, Oscar. O retrato de Dorian Gray (romance); Poesia; Teatro (Salomé); Estórias e Contos; Conferências e Ensaios; De Profundis e outros escritos, em: Obra Completa - volume único. Introdução, estudo biográfico-crítico e cronologia da vida e obra: James Laver. Rio de Janeiro: Nova Aguilar, 2003.

WOLFE, Tom. A palavra pintada. Porto Alegre: L\&PM, 1987.

\section{Resumo}

Este ensaio analisa comparativamente a novela A confissão de Lúcio, do português Mário de Sá-Carneiro, e o romance O retrato de Dorian Gray, do irlandês Oscar Wilde, focalizando as discussões éticas e estéticas por eles veiculadas, sobretudo no que se refere à questão pós-moderna da supremacia do ego sobre a obra de arte.

\section{Abstract}

This essay analyses comparatively the novel Lucio's confession, written by the portuguese Mário de Sá-Carneiro, and the novel The portrait of Dorian Gray, written by the irish Oscar Wilde, focalizing the aspects discussed by them, specially the ones related to the postmodernist question of the supremacy of the ego over the artwork. 